\title{
First observation of a nocturnal nudibranch feeding on Caribbean corals
}

Received: 17 August 2010/Accepted: 22 August 2010/Published online: 20 October 2010

(C) Springer-Verlag 2010

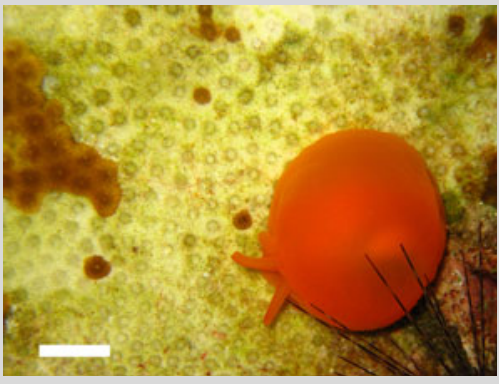

Fig. 1 An individual Berthellina quadridens that has stopped feeding on Montastraea faveolata tissue and is moving toward a crevice. In the background, the bare skeleton exposed by consumption of the overlying tissue shows the early stages of overgrowth by turf algae. Scale bar $=1 \mathrm{~cm}$

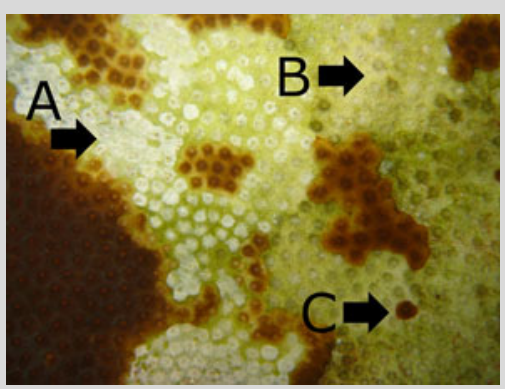

Fig. 2 Feeding scars resulting from predation by $B$. quadridens. a Newly exposed skeleton in an area where $B$. quadridens was feeding less than 1 min prior. b New overgrowth of turf algae in an area where $B$. quadridens fed 3 days earlier. c Surviving single polyps appear to be typical for feeding scars left by $B$. quadridens
In November 2009, slugs of the family Pleurobranchidae $(n=12)$ were observed feeding on separate colonies of the dominant Caribbean reef-building corals Montastraea faveolata and M. annularis in Curaçao, Netherlands Antilles (Fig. 1). Individuals were 5-7 cm in length and observed at night between 22:00 and 01:00 h. They are likely Berthellina quadridens (Mörch 1863) though in situ visual identification of these slugs is difficult. B. quadridens is a cosmopolitan species that is rarely observed in the Caribbean (Humann and DeLoach 2002). The species quickly hides when exposed to light, which means that many of these nudibranchs likely disappear before divers notice them.

During feeding, B. quadridensis completely removed the coral's tissue and recently eaten areas had become overgrown by fine turf algae (Fig. 2). Slugs returned on consecutive nights and resumed feeding on the already-affected coral surface. The species is capable of acid secretion that is hypothesized to aid in feeding, penetrating calcareous material, and defense (Thompson 1988).

Importantly, the feeding scars left by these nocturnal coral predators could easily be mistaken for tissue necrosis or disease when observed during the day when the predator is not visible. Feeding scars are characterized by areas of denuded coral skeleton that is overgrown by thin turf algae, and often single polyps and small areas of live tissue are present within the borders of the feeding area (Fig. 2). Nightly predation on corals is known in other Caribbean invertebrates (e.g., the fire worm Hermodice carunculata or the gastropod Coralliophila abbreviata), but the feeding scars left by $B$. quadridensis are much larger (up to $15 \times 20 \mathrm{~cm}$ ) than those left by these other corallivores. The total ecological impact of B. quadridensis feeding on corals is unknown. This observation highlights however how the effects of small, cryptic coral predators may be mistaken for disease and demonstrates the importance of natural history observations at all times of day and night.

\section{References}

Humann P, DeLoach N (2002) Reef creature identification. New World Publications, Inc., FL, p 448

Mörch OAL (1863) Contributions a la Faune malacologique des Antilles danoises. Journal de Conchyliologie 11:21-43

Thompson TE (1988) Acidic allomones in marine organisms. J Mar Biol Assoc UK 68:499-517

M. J. A. Vermeij ( $₫)$

CARMABI, Piscaderabaai z/n, Willemstad, Curaçao, Netherlands Antilles

e-mail: m.vermeij@carmabi.org

M. J. A. Vermeij

IBED, University of Amsterdam, Nieuwe Achtergracht 127, 1018 WS Amsterdam, The Netherlands



Coral Reefs (2010) 29:1047

DOI $10.1007 / \mathrm{s} 00338-010-0685-3$ 